\title{
Hydraulic performance of new and used self-compensating micro-sprinklers
}

\author{
Desempenho hidráulico de microaspersor autocompensante, \\ novo e usado
}

\author{
Stocler Manoel de Andrade ${ }^{1}$; José Renato Zanini ${ }^{2}$ Cristiana Araujo Soares ${ }^{3 *}$
}

\begin{abstract}
From the technical and economic perspectives, it is imperative that irrigation systems have extensive durability and high uniformity of application. The objective of this study was to compare the hydraulic performance of new and used (9 years of use with $4265 \mathrm{~h}$ of operation) self-compensating microsprinklers of the SuperNet LR model. The study was performed in a laboratory to evaluate flow in the range of pressure compensation, coefficient of manufacturing variation or discharge (CVF and CVQ), wetting pattern, distribution uniformity coefficient (DUC), and Christiansen uniformity coefficient (CUC).The new and used micro-sprinklers did not differ in CVF and CVQ, and were rated as excellent; they also did not differ in CUC or DUC. The coverage diameters of the new and used micro-sprinklers were the same as those given in the manufacturer's catalog. There were no significant differences in the flow rates of the new and used micro-sprinklers when subjected to the same pressure, but significant differences in flow rate were observed within the range of pressure compensation. When installed in an irrigation system, the useful life of micro-sprinklers can be considered to be greater than 9 years with $4265 \mathrm{~h}$ of operation.
\end{abstract}

Key words: Water distribution, localized irrigation, micro-irrigation

\section{Resumo}

Tecnicamente e economicamente, é imperativo que os sistemas de irrigação apresentem ampla durabilidade e elevada uniformidade de aplicação de água. O objetivo deste trabalho foi comparar o desempenho hidráulico de microaspersor autocompensante modelo SuperNet LR, novo e usado com 4.265 horas de funcionamento e 9 anos de instalação. $O$ trabalho foi realizado em condições de laboratório, avaliando-se a vazão no intervalo de compensação de pressão, o coeficiente de variação de fabricação ou vazão (CVF e CVQ), o padrão de molhamento, o coeficiente de uniformidade de distribuição (CUD) e o coeficiente de uniformidade de Christiansen (CUC). Os microaspersores novos e usados não diferiram em relação ao CVF e CVQ, sendo classificados como excelentes, não diferindo também em relação aos coeficientes CUC e CUD. Os diâmetros de cobertura dos microaspersores novos e usados foram iguais ao apresentado no catálogo do fabricante. Não houve diferenças significativas nas vazões dos microaspersores novos e usados quando submetidos à mesma pressão de operação, porém houve diferenças significativas de vazões dentro do intervalo de compensação de pressão. Para as condições onde está instalado o sistema de irrigação, a vida útil dos microaspersores pode ser considerada maior que 9 anos de utilização ou 4.265 horas de funcionamento.

Palavras-chave: Distribuição de água, irrigação localizada, microirrigacão

${ }^{1}$ Eng $^{\circ}$ Agro , M.e em Agronomia,Ciência do Solo, Universidade Estadual Paulista "Júlio de Mesquita Filho", UNESP, Jaboticabal, SP, Brasil. E-mail: stocler@stocler.com.br

2 Prof. Dr., Dept ${ }^{0}$ de Engenharia Rural, UNESP, Jaboticabal, SP, Brasil. E-mail: jrzanini@fcav.unesp.br

${ }^{3}$ Discente de Doutorado em Agronomia, Irrigação e Drenagem, Dept ${ }^{\circ}$ de Engenharia Rural, UNESP, Botucatu, SP, Brasil. E-mail: criwan_1@hotmail.com

* Autor para correspondência 


\section{Introduction}

Localized irrigation, also known as microirrigation (CUNHA et al., 2008; FRIZZONE et al., 2012), is a practice whereby water is directly supplied to the soil and near the root system of plants, with low intensity and high frequency, providing hydric conditions favorable to crop development. When properly employed, localized irrigation is an effective tool for increasing the productivity and profitability while allowing fertigation, promoting better use of fertilizers, and enabling the installment of fertilizer application according to the frequency of irrigation (MANTOVANI et al., 2012). Other advantages of localized irrigation include labor saving, possibility of application in different types of topography and soil, more efficient use of water and phytosanitary control by not wetting the aerial parts of plants, and minimizing the costs associated with the use of insecticides and fungicides.

Micro-sprinklers, which use emitters for sprinkling, are one of the localized irrigation systems. Micro-sprinklers are similar to sprinklers, but their small size enables them to launch small fan-shaped water jets into small droplets as a continuous or fractional jet, with or without rotary motion. A micro-sprinkler system is preferred for irrigation in areas with sandy soil because it allows for a larger wet bulb diameter compared with a drip system (MANTOVANI et al., 2012).However, micro-sprinklers also have some disadvantages, the most notable being a high risk of clogging of emitters and increased flow rate due to wear when used excessively. These drawbacks make it essential that the hydraulic characteristics of emitters are determined when they are introduced in the market and further when in use in the field. According to Lemos Filho et al. (2011), in localized irrigation, many factors may affect the uniformity of water distribution, such as the uniformity of new and used emitters, an improper sizing system, and the imbalance of flow of emitters caused by mineral or organic particles present in the water.
The main purpose of testing equipment used in localized irrigation systems is to evaluate their hydraulic characteristics. These characteristics are the relationship between pressure and flow rate, manufacturing uniformity, magnitude of the effective radius, and uniformity of water distribution in the radial direction. According to Souza et al. (2005), determining the efficiency of an irrigation system is necessary to conduct systematic evaluations, which requires an analysis of factors such as wetted surface and evaluation of the functioning of accessories such as emitters, filters, pressure regulators, and volumetric valves.

With the increased irrigated area in Brazil and the high demand for localized irrigation equipment, the number of manufacturers of such equipment, as well as importers of micro-sprinklers with a high level of manufacturing technology, has increased in the Brazilian market. However, there is a lack of knowledge of the operating behavior of these emitters when subjected to prolonged use. The aging and wear of emitter components are considered to alter its original hydraulic behavior, influencing the application of water and consequently disrupting the design of the initially established project for the irrigated area. In particular, when considering self-compensating micro-sprinklers, the selfcompensating mechanism is carried out using a silicone membrane; regardless of their resistance in differing physical, chemical, and biological water quality, the products used in fertigation or to solve fouling problems have been observed to alter the rigidity of the membrane. Therefore, in addition to the knowledge of the hydraulic behavior of the designed system, knowledge of the functioning of micro-sprinklers over time is essential to predicting the system's lifetime, which has implications for the economic return of irrigated crops investment.

To determine the influence of operating life time on the hydraulic behavior of localized irrigation emitters, this study aimed to evaluate the hydraulic performance of new and used self-compensating micro-sprinklers of the SuperNet LR model manufactured by Netafim. 


\section{Materials and Methods}

We used ten new and used self-compensating micro-sprinklers (SuperNet LR 035, Netafim) with a light blue nozzle, $1.2 \mathrm{~mm}$ diameter, $35 \mathrm{~L} \mathrm{~h}^{-1}$ nominal flow rate, purple rotor, and pressure compensation range of 170 to $450 \mathrm{kPa}$ (Figure 1). The new emitters were purchased directly from the manufacturer with the same specifications as the used emitters.

Figure 1. Parts of the SuperNet LR micro-sprinkler; (A) new, (B) used, and (C) mounted micro-sprinklers (new and used).
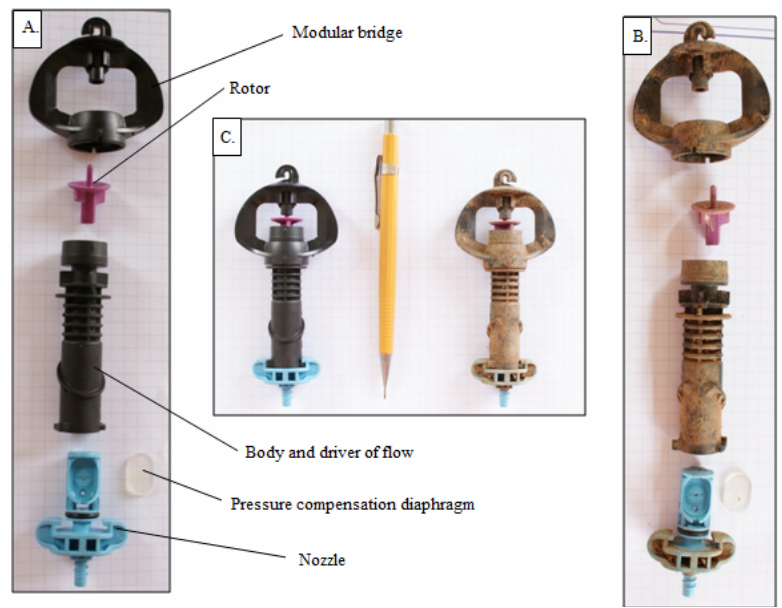

The used micro-sprinklers were obtained from an automated irrigation system implemented in 2003 in the city of Barretos, São Paulo, with artesian water (water analysis report shown in Figure 2) for irrigation of mature orange trees, and with a hydrocyclone system to separate suspended solids and automated screen filters with a 120 mesh filter element. The micro-sprinklers were in use for 9 years and operated for $4265 \mathrm{~h}$. To determine the operating time, we used a utility electricity meter that had the same month and year of installation as the implementation of the irrigation system and was exclusively used for this system. In addition, considering that the system consisted of four sectors, that the unit power was fixed and expressed in $\mathrm{kW}$, and that the total amount consumed was expressed in $\mathrm{kWh}$, the operating time was determined in hours.

For the flow pressure and distribution of water, we installed a $1 \mathrm{cv}(736 \mathrm{~W})$ pump with a maximum flow rate and pressure of $3 \mathrm{~m}^{3} \mathrm{~h}^{-1}$ and $550 \mathrm{kPa}$, respectively. In the downstream of the pump, we installed a plastic filter with 120 mesh discs, 1" slide valve, and Bourdon-type glycerin manometer with a scale from 1 to $7 \mathrm{kgf} \mathrm{cm}^{-2}$, used for first approximation of the required pressures. For accurate pressure measurements, we used a $3.9 \mathrm{~m}$ high mercury column manometer connected to the input of the micro-sprinklers. Pressure adjustment of the micro-sprinklers was performed using a needle record in the supply line of the input, and the water supply was derived from a constant-level tank installed outside the laboratory.

For the flow uniformity test, we set up a bench of $2.9 \mathrm{~m}$ length and $1.52 \mathrm{~m}$ height (Figure 3 ). We connected a supply line with five micro-sprinklers spaced at intervals of $0.48 \mathrm{~m}$; on top of each microsprinkler, a glass bell was placed to intercept the water jet and then direct to plastic pails with a capacity of $15 \mathrm{~L}$. The collection time was $5 \mathrm{~min}$ according to ABNT (2004), which determines the minimum collection time to be $1 \mathrm{~min}$ for a container with a minimum capacity of $15 \mathrm{~L}$. Subsequently, pre-weighed buckets were weighed on an electronic scale with a capacity of $10 \mathrm{~kg}$ and precision of 0.1 
g. For the test, we used a completely randomized design with three replications and $2 \times 4$ type distribution, with the new and used micro-sprinklers as levels and four test pressures $(170,250,350$, and $450 \mathrm{kPa}$ ) as factors. The significance was analyzed (F test) at 0.01 probability, and we applied the Tukey test at the 0.05 significance level for the means.
The maximum variations and mean flow rates were classified according to ABNT (2004). With data from this analysis, we determined the coefficient of manufacturing variation (CVF) using equation 1 , and then the results were classified according to ASABE (2008).

Figure 2. Water analysis report aimed at irrigation, conducted by the Lanatec laboratory in Sao Jose do Rio Preto.

\begin{tabular}{|c|c|c|c|c|}
\hline \multicolumn{3}{|c|}{$\begin{array}{l}\text { Requested by: Stocler Irrigation Ltd. } \\
\text { Address: Fazenda Boa Sorte } \\
\text { Analyzed material: Underground Water } \\
\text { Date/Received: August } 22,2012 \quad \text { Date/Started: August } 23,2012 \\
\text { Coordinates: } 20^{\circ} 40^{\prime} 42.35^{\prime \prime} \mathrm{S}-48^{\circ} 41^{\prime} 47.69^{\prime \prime} \mathrm{W}\end{array}$} & \multicolumn{2}{|c|}{$\begin{array}{l}\text { City: Barretos-SP (Brazil) } \\
\text { Responsible for collection: Stocler M. de Andrade } \\
\text { Collection/Time: } 15: 30 \text { Temperature: } 20^{\circ} \mathrm{C} \\
\text { Elevation: } 578 \mathrm{~m}\end{array}$} \\
\hline Parameter & Unit & ${ }^{\star} \mathbf{Q L}$ & Results & $\star *$ MAV \\
\hline Iron & $\mathrm{mg} / \mathrm{L}$ & 0.1 & $<0.1$ & 0.3 \\
\hline Manganese & $\mathrm{mg} / \mathrm{L}$ & 0.1 & $<0.1$ & 0.1 \\
\hline Total dissolved solids & $\mathrm{mg} / \mathrm{L}$ & 1.0 & 114.4 & 1000 \\
\hline Suspended solids & $\mathrm{mg} / \mathrm{L}$ & 0.01 & 6.0 & - \\
\hline Hydrogen sulfate & $\mathrm{mg} / \mathrm{L}$ & 0.001 & $<0.001$ & 0.1 \\
\hline $\mathrm{pH}$ & Dimensionless & 0.1 & 8.54 & 6.0 to 9.5 \\
\hline
\end{tabular}

Source: Lanatec laboratory.

Figure 3. Test bench for flow uniformity and coefficient of manufacturing variation of micro-sprinklers.

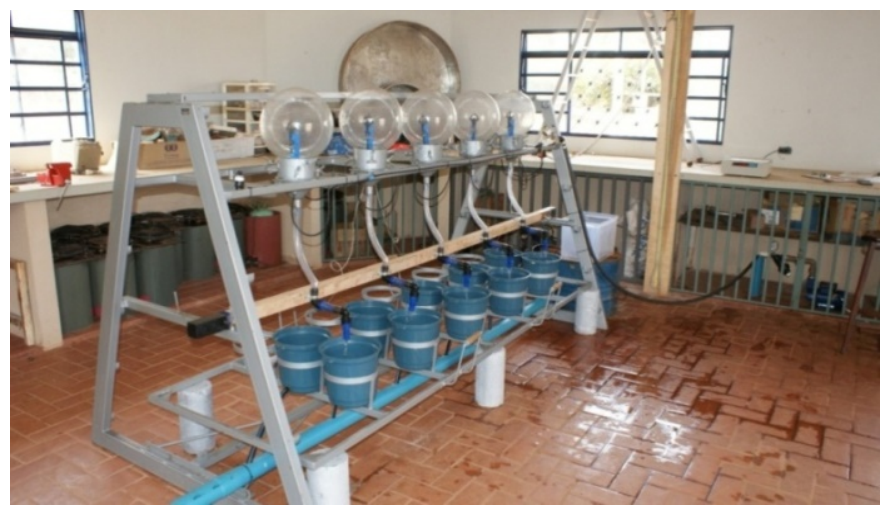

$$
\mathrm{CVF} \text { or } \mathrm{CVQ}=100 \frac{\sqrt{\sum_{i=1}^{n} \frac{(q i-q m)^{2}}{n-1}}}{q m}
$$

where CVF or CVQ is the coefficient of manufacturing variation or flow $(\%), \mathrm{q}_{\mathrm{i}}$ is the flow rate of each emitter $\left(\mathrm{L} \mathrm{h}^{-1}\right), \mathrm{q}_{\mathrm{m}}$ is the mean flow rate of emitters $\left(\mathrm{L} \mathrm{h}^{-1}\right)$, and $\mathrm{n}$ is the number of emitters of the sampling batch.

To determine the uniformity of water distribution, coverage diameter, and standard wet and uniformity coefficients (DUC and CUC),we selected four 
emitters, numbered 2, 4, 6, and 9, in an ascending order of flow from both new and used emitters for use in replications, as recommended by ABNT (2004). On the laboratory floor, we distributed 210 collectors in a mesh shape with $0.08 \mathrm{~m}$ diameter and $0.102 \mathrm{~m}$ height, with a spacing of $0.5 \mathrm{~m}$ between the collectors and the micro-sprinkler located in the center of the mesh (Figure 4). In the same mesh, we also arranged two rows of collectors whose center point coincided with the micro-sprinkler's position to obtain the radial profile of water distribution. The micro-sprinklers were operated individually and sequentially for $1 \mathrm{~h}$ at a continuous pressure of $300 \mathrm{kPa}$, which was the approximate mean value of the pressure compensation range (170-450 kPa). Next, we determined the stored volume in each collector and transformed it to the application rate $\left(\mathrm{mm} \mathrm{h}^{-1}\right)$. The coverage diameter was determined by multiplying the average radius by 2 , by discarding the collectors with application rates lower than 0.13 $\mathrm{mm} \mathrm{h}^{-1}$ (ABNT, 2004).

Figure 4. Distribution of collectors in rectangular mesh.

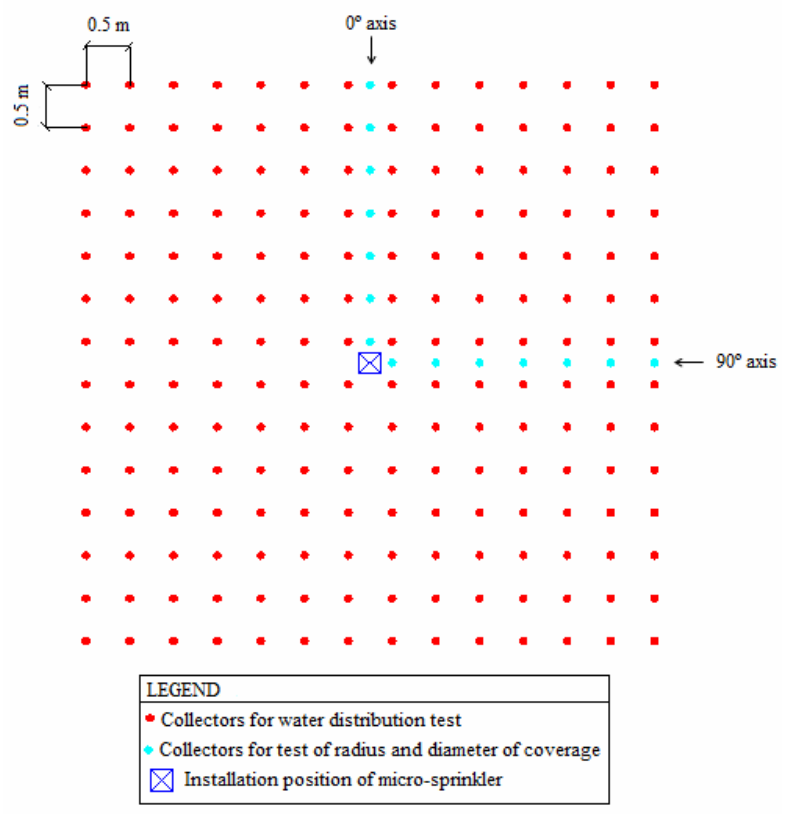

To determine CUC and DUC, we used equation 2 and 3, respectively, for a $100 \%$ overlap of the radial range of the micro-sprinklers (spacing of $3 \times$ $3 \mathrm{~m}$ between micro-sprinklers, based on the range indicated in the manufacturer's catalog), and then ranked the performance according to Mantovani et al. (2012).

$$
\mathrm{CUC}=100\left(1-\frac{\sum_{i=1}^{n}\left|Y_{i}-\bar{Y}\right|}{n \bar{Y}}\right)
$$

where CUC is the Christiansen's uniformity coefficient (\%), Yis the water blade collected in the $\mathrm{i}^{\text {th }}$ collector $(\mathrm{mm}), \overline{\mathrm{Y}}$ is the mean water blade collected (mm), and $\mathrm{n}$ is the number of observations.

$$
\mathrm{DUC}=100\left(\frac{q n}{\bar{q}}\right)
$$

where DUC is the distribution uniformity coefficient $(\%), \mathrm{q}_{\mathrm{n}}$ is the mean of the smallest precipitations, representing $25 \%$ of total assessed, and $\overline{\mathbf{q}}$ is the mean of all collected precipitations.

\section{Results and Discussion}

From Table 1, we see that the new and used microsprinklers had no significant differences in flow rate variations when operated under the same pressure. The maximum variations were higher than $10 \%$ of the flow rates only when subjected to a pressure of $250 \mathrm{kPa}$, and the mean variations were higher than $7 \%$. These were classified as unacceptable based on ABNT (2004), which states that self-compensating micro-sprinklers should have maximum variations less than $10 \%$ of the flow rates within the pressure compensation range and variations of average flow rates less than $2.5 \%$ of the nominal flow rate. Sandri et al. (2010) evaluated the influence of operating lifetime of a micro-sprinkler at $250 \mathrm{kPa}$ pressure and obtained variations in the mean flow rate (6\% and $9.2 \%$ for new and used micro-sprinklers, respectively) greater than those found in this study. 
Table 1. Maximum flow rate variation with pressure within the pressure compensation range and mean variation for the two states of use of SuperNet micro-sprinklers, with a nominal flow rate of $35 \mathrm{~L} \mathrm{~h}^{-1}$.

\begin{tabular}{cccccccc}
\hline \multirow{2}{*}{ State of use } & $\begin{array}{c}\text { Pressure } \\
(\mathrm{kPa})\end{array}$ & $\begin{array}{c}\text { Flow } \\
\left(\mathrm{L} \mathrm{h}^{-1}\right)\end{array}$ & \multicolumn{2}{c}{ Maximum Variation } \\
$\left(\mathrm{L} \mathrm{h}^{-1}\right)$ & $(\%)$ & $\begin{array}{c}\text { Mean flow } \\
\left(\mathrm{L} \mathrm{h}^{-1}\right)\end{array}$ & $\begin{array}{c}\text { Mean variation } \\
\left(\mathrm{L} \mathrm{h}^{-1}\right)\end{array}$ & $\begin{array}{c} \\
(\%)\end{array}$ \\
\hline \multirow{3}{*}{ New } & 170 & $35.46 \mathrm{~A}$ & 0.46 & 1.32 & & & \\
& 250 & $39.07 \mathrm{~B}$ & 4.07 & 10.42 & 37.55 & 2.55 & \\
& 350 & $37.52 \mathrm{C}$ & 2.52 & 6.73 & & & \\
& 450 & $38.16 \mathrm{D}$ & 3.16 & 8.30 & & & \\
\multirow{3}{*}{ Used } & 170 & $35.29 \mathrm{~A}$ & 0.29 & 0.84 & & \\
& 250 & $38.93 \mathrm{~B}$ & 3.93 & 10.10 & 37.55 & & \\
& 350 & $37.48 \mathrm{C}$ & 2.48 & 6.62 & & & \\
& 450 & $38.50 \mathrm{D}$ & 3.50 & 9.10 & & & \\
\end{tabular}

The capital letters in the third column compare the means between the two emitters for the same pressure. Means with the same letter do not differ statistically based on the Tukey test at the 0.05 significance level.

Table 2 summarizes the results of an analysis of variance. The test results are significant at 0.01 probability for the effect of pressure, indicating that there were differences between flow rates when the micro-sprinklers were subjected to different pressures. Nevertheless, the differences were not significant between the new and used microsprinklers, and therefore the used micro-sprinklers did not differ from the new micro-sprinklers in terms of flow. The coefficient of variation was $3.8 \%$.

From the Tukey test (Table 3), it appears that only the flow rate obtained at $450 \mathrm{kPa}$ did not differ from the flow rates in the range of $250 \mathrm{kPa}$ to 350 $\mathrm{kPa}$ for the new and used emitters.

From the flow rate $\left(\mathrm{q} ; \mathrm{L} \mathrm{h}^{-1}\right)$ and pressure $(\mathrm{H}$; $\mathrm{kPa})$ data and potential regression analysis, we determined the characteristic equation for the new emitters as $\mathrm{q}=26.876 \mathrm{H}^{0.0591}\left(\mathrm{R}^{2}=0.3655\right)$ and for the used emitters as $\mathrm{q}=25.016 \mathrm{H}^{0.0717}\left(\mathrm{R}^{2}=0.4767\right)$. In both scenarios, even with low coefficients of determination, the discharge exponent " $x$ " was close to zero, which is a characteristic of selfcompensating micro-sprinklers. However, there were no significant differences between flow rates (Table 3), and the micro-sprinklers cannot be considered fully self-compensating. According to Frizzone et al. (2012), a perfect emitter should have an exponent $\mathrm{x}$ equal to zero, to cancel the effect of pressure variation on emitter flow rate variations. Miola et al. (2009) studied a non-self-compensating emitter and obtained an $\mathrm{x}$ of 0.635 , characterizing it as a turbulent flow. Cunha et al. (2010) obtained an $\mathrm{x}$ of 0.7179 for an unregulated emitter (Amanco MF) with a $1.14 \mathrm{~mm}$ nozzle.

Table 2.Summary of the analysis of variance for flow rates in relation to pressure and use status (new and used).

\begin{tabular}{lllll}
\hline Cause of variation & GL & SQ & QM & Factor F \\
\hline Pressure (p) & 3 & 148.606 & 49.535 & $34.8070^{* *}$ \\
State of use(e) & 1 & 0.001 & 0.001 & 0.0004 \\
Interaction (p; e) & 3 & 0.822 & 0.274 & 0.1926 \\
\hline (Treatments) & 7 & 149.428 & & \\
Residue & 72 & 102.466 & 1.423 & \\
\hline Total & 79 & 251.894 & & \\
\hline
\end{tabular}

$* *$ Significant at 0.01 probability, $\mathrm{F}_{(3 ; 72)}$ table $=4.1$. 
Table 3. Average flow rate of new and used micro-sprinklers within the pressure compensation range.

\begin{tabular}{ccc}
\hline Pressure $(\mathrm{kPa})$ & $\begin{array}{c}\text { New micro-sprinkler } \\
\text { Mean flow rate }\left(\mathrm{L} \mathrm{h}^{-1}\right)\end{array}$ & $\begin{array}{c}\text { Used Micro-sprinkler } \\
\text { Mean flow rate }\left(\mathrm{L} \mathrm{h}^{-1}\right)\end{array}$ \\
\hline 170 & $35.467 \mathrm{c}$ & $35.295 \mathrm{c}$ \\
250 & $39.073 \mathrm{a}$ & $38.930 \mathrm{a}$ \\
350 & $37.524 \mathrm{~b}$ & $37.482 \mathrm{~b}$ \\
450 & $38.167 \mathrm{ab}$ & $38.502 \mathrm{ab}$ \\
\hline
\end{tabular}

Means followed by the same letter(s) do not differ statistically (vertically) based on the Tukey test at the 0.05 significance level.

Table 4 presents the mean values and ratings of CVF and CVQ. Based on ASABE (2008), both the new and used emitters were classified as excellent under all pressures. Sandri et al. (2010) employed pressures of 250 and $350 \mathrm{kPa}$ for new and used micro-sprinklers of a modular group and obtained a CVF of $1.3 \%$ and $1.3 \%$ and CVQ of $2.4 \%$ and $3.2 \%$, respectively. Cunha et al. (2010) employed a pressure of 100 to $250 \mathrm{kPa}$ for an Amanco MF micro-sprinkler and obtained a mean CVP of $2.29 \%$, ranking the micro-sprinkler as excellent.

Using the water distribution test, we determined the radius and diameter of the micro-sprinkler's coverage. For the new micro-sprinklers, in all replications, radius $1\left(0^{\circ}\right.$ axis, in blue $)$ and $2\left(90^{\circ}\right.$ axis, in red) were 2.75 and $3.25 \mathrm{~m}$, respectively (Figure 5), with an average radius of $3 \mathrm{~m}$. The difference between radius 1 and 2 is likely related to the interference of the emitting modular bridge, which restricted the supply of water along the $0^{\circ}$ axis. For the used micro-sprinklers (Figure 6), only number 4 had both the radii at $2.75 \mathrm{~m}$; this reduction may have been caused by rotor dryness and adhesion of impurities, especially salts, or wear of rotating components, which changed the water jet angle (SANDRI et al., 2010). The coverage diameter of the new micro-sprinklers was $6 \mathrm{~m}$ according to the data provided by the manufacturer. For the used micro-sprinklers, the diameter ranged from 5.50 to $6.50 \mathrm{~m}$ and can be adopted as $6.00 \mathrm{~m}$ on average.

Table 4. Classification of manufacturing variation coefficient for new and used emitters in the pressure compensation range.

\begin{tabular}{cccc}
\hline Micro-sprinkler & Pressure $(\mathrm{kPa})$ & CVF and CVQ & ASABE (2008) classification \\
\hline \multirow{3}{*}{ New } & 170 & 0.01 & Excellent \\
& 250 & 0.04 & Excellent \\
& 350 & 0.03 & Excellent \\
& 450 & 0.03 & Excellent \\
Mean & 0.02 & Excellent \\
\hline \multirow{5}{*}{ Used } & 170 & 0.02 & Excellent \\
& 250 & 0.03 & Excellent \\
& 350 & 0.04 & Excellent \\
& 450 & 0.04 & Excellent \\
& Mean & 0.03 & Excellent \\
\hline
\end{tabular}


Figure 5. Radial profile of new micro-sprinkler (A) 2, (B) 4, (C) 6, and (D) 9.
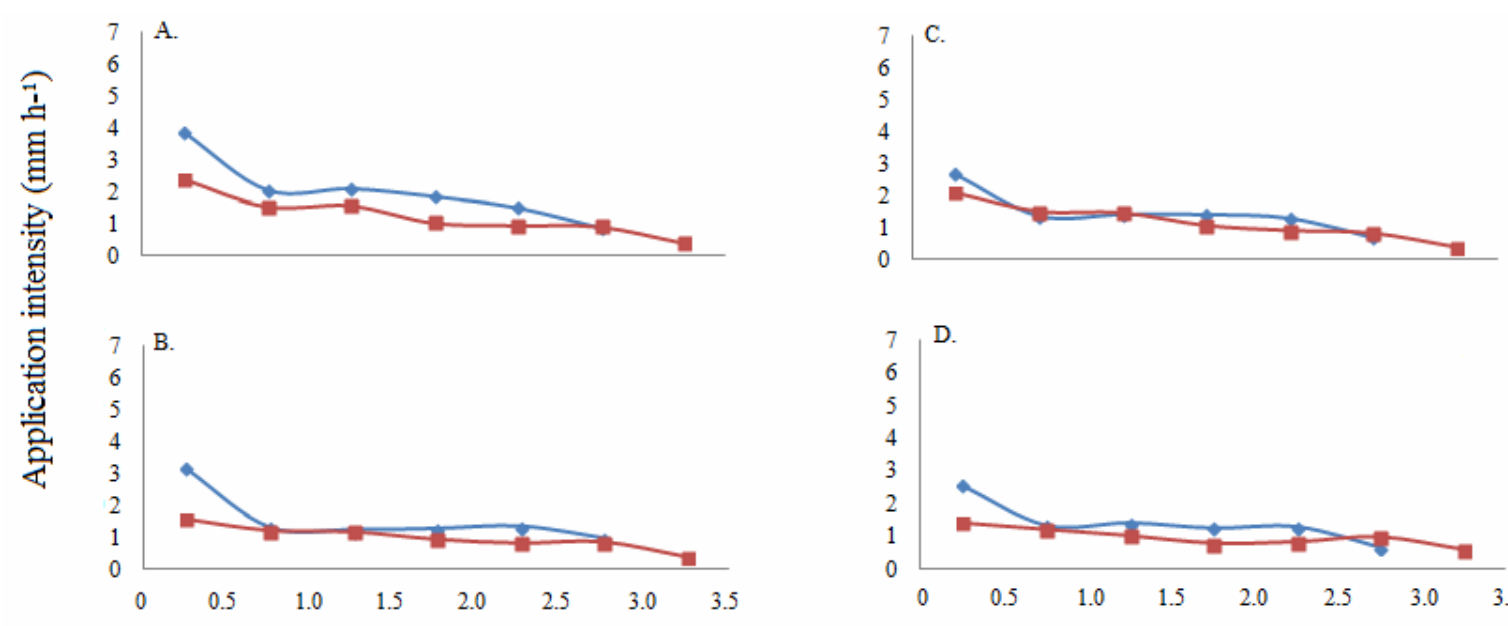

Collector distance from micro-sprinkler (m)

$\rightarrow$ Radius $1\left(0^{\circ}\right.$ axis $) \quad \rightarrow$ Radius $2\left(90^{\circ}\right.$ axis $)$

Figure 6. Radial profile of used micro-sprinkler (A) 2, (B) 4, (C) 6, and (D) 9.
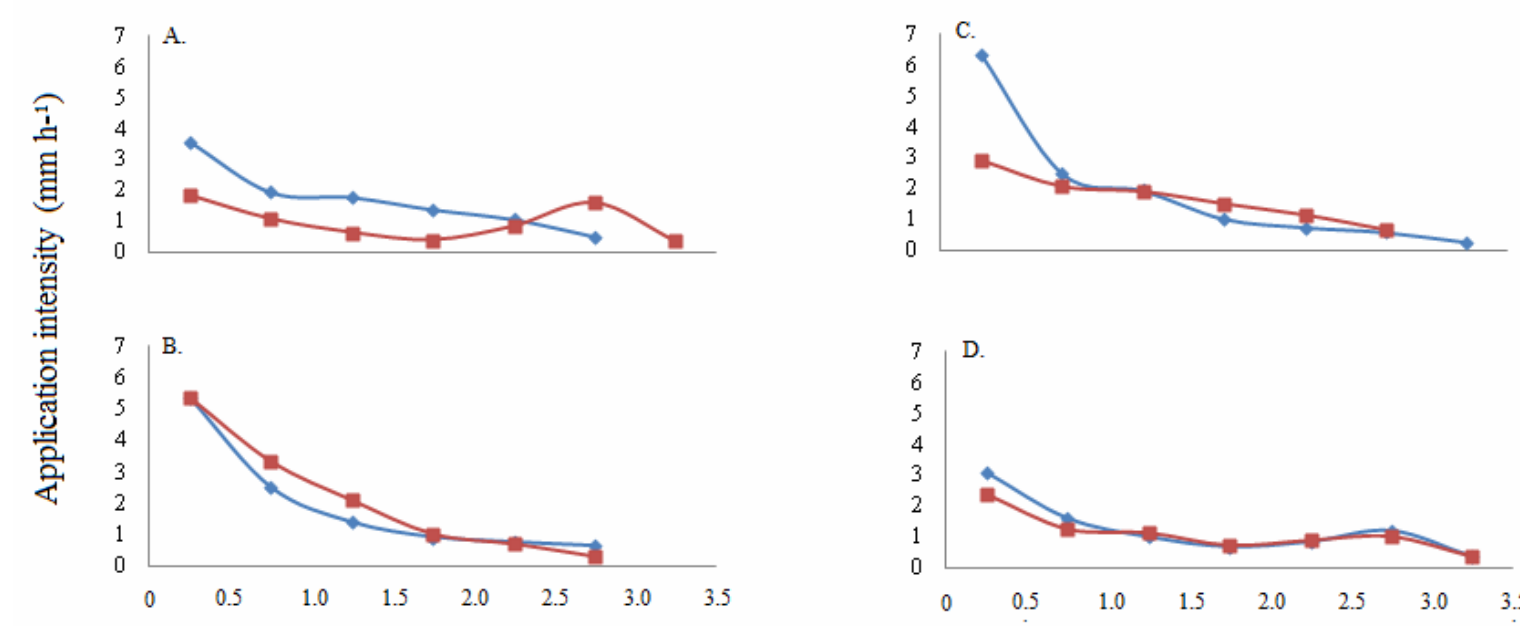

Collector distance from micro-sprinkler (m)

$\rightarrow$ Radius 1 ( $0^{\circ}$ axis $) \quad \rightarrow$ Radius 2 (90 axis)

Conceição and Coelho (2004) studied a Dan 2001 micro-sprinkler with a $1.10 \mathrm{~mm}$ nozzle and nominal flow rate of $35 \mathrm{~L} \mathrm{~h}^{-1}$ and obtained an operating range of $2.4 \mathrm{~m}$; the highest application rate was $2.9 \mathrm{~mm} \mathrm{~h}^{-1}$ at $1.2 \mathrm{~m}$ from the micro-sprinkler. Using nozzles of a higher flow rate, there was an increase in the range from 3 to $3.6 \mathrm{~m}$ and greater application intensities of
4.3 to $5.9 \mathrm{~mm} \mathrm{~h}^{-1}$ in the collectors located $0.5 \mathrm{~m}$ from the emitter. Similar results were obtained by Sandri et al. (2010), who found a greater precipitation at $1.0 \mathrm{~m}$ with a new modular micro-sprinkler than with a used model, which decreased the precipitation at $0.5 \mathrm{~m}$ following a rise. 
Based on the standard wetting isograms (Figures 7 and 8), larger application intensities were obtained at $0.25 \mathrm{~m}$ from the micro-sprinkler, with a maximum of 4 to $5 \mathrm{~mm} \mathrm{~h}^{-1}$ and gradually decreasing with increasing distance. Considering a circular area of $28.27 \mathrm{~m}^{2}$ for a $3 \mathrm{~m}$ range, $17.4 \%$ of the area had an application rate of 2 to $5 \mathrm{~mm} \mathrm{~h}^{-1}$ and the remaining $82.6 \%$ had a lower application rate of $2 \mathrm{~mm} \mathrm{~h}^{-1}$. Furthermore, Figure 7 and 8 show that the modular bridge that supports the rotor interferes with the reach capacity and the efficacy of the wetting pattern.

Cunha et al. (2010) conducted tests in field conditions with an Amanco MF $63 \mathrm{~L} \mathrm{~h}^{-1}$ microsprinkler at an operating pressure of $200 \mathrm{kPa}$ and obtained irregular distribution patterns, with precipitation exceeding $5 \mathrm{~mm} \mathrm{~h}^{-1}$ in the range of 0.3 $\mathrm{m}$ away from the emitter and decreasing gradually with further distance.

With a $100 \%$ overlapping range $(3 \mathrm{~m} \times 3 \mathrm{~m})$ for the new micro-sprinklers, the means of CUC and DUC were 83.6 and $75.2 \%$, respectively (Table 5). For the used micro-sprinklers, these values were $84.1 \%$ and $75.9 \%$, respectively. Statistically, the F-test results were not significant at 5\% probability, and therefore CUC and DUC did not differ between the new and used emitters. The coefficient of variation was $4.1 \%$ and $6.5 \%$ for CUC and DUC, respectively. It is noteworthy that the test with $100 \%$ overlapping range enables comparison of water distribution between new and used micro-sprinklers, because for micro-sprinklers in the field, an overlap in a square pattern is not used because irrigation is performed in lanes. In addition, achieving a $100 \%$ wetted area is not an objective.

Table 5. Values of CUC and DUC (\%) for new and used micro-sprinklers with 100\% overlap (3m×3 m).

\begin{tabular}{|c|c|c|c|c|c|c|}
\hline \multirow{2}{*}{ State of use } & \multirow{2}{*}{$\begin{array}{c}\text { CUC and DUC } \\
(\%)\end{array}$} & \multicolumn{4}{|c|}{ Replication } & \multirow{2}{*}{ Mean } \\
\hline & & I (2) & II (4) & III (6) & IV (9) & \\
\hline \multirow{2}{*}{ New } & CUC & 84.2 & 84.8 & 83.2 & 82.3 & 83.6 \\
\hline & DUC & 73.1 & 76.7 & 77.6 & 73.3 & 75.2 \\
\hline \multirow{2}{*}{ Used } & CUC & 79.9 & 80.6 & 90.0 & 86.0 & 84.1 \\
\hline & DUC & 69.4 & 71.0 & 82.3 & 80.8 & 75.9 \\
\hline
\end{tabular}

Figures in parentheses are identification numbers of micro-sprinklers.

Based on Mantovani et al. (2012), the new and used micro-sprinklers presented CUC and DUC values that can be classified as good in terms of uniformity of distribution. The values of CUC and DUC, even though classified as good, could be better if the amount of supplied water was more uniform, thus preventing large concentration of water near the emitter. According to Silva and Silva (2005), a high concentration of water near the base of the emitter is indicative of a lack of uniformity in systems using micro-sprinklers. 
Figure 7. Wetting isograms of new micro-sprinkler (A) 2, (B) 4, (C) 6, and (D) 9.
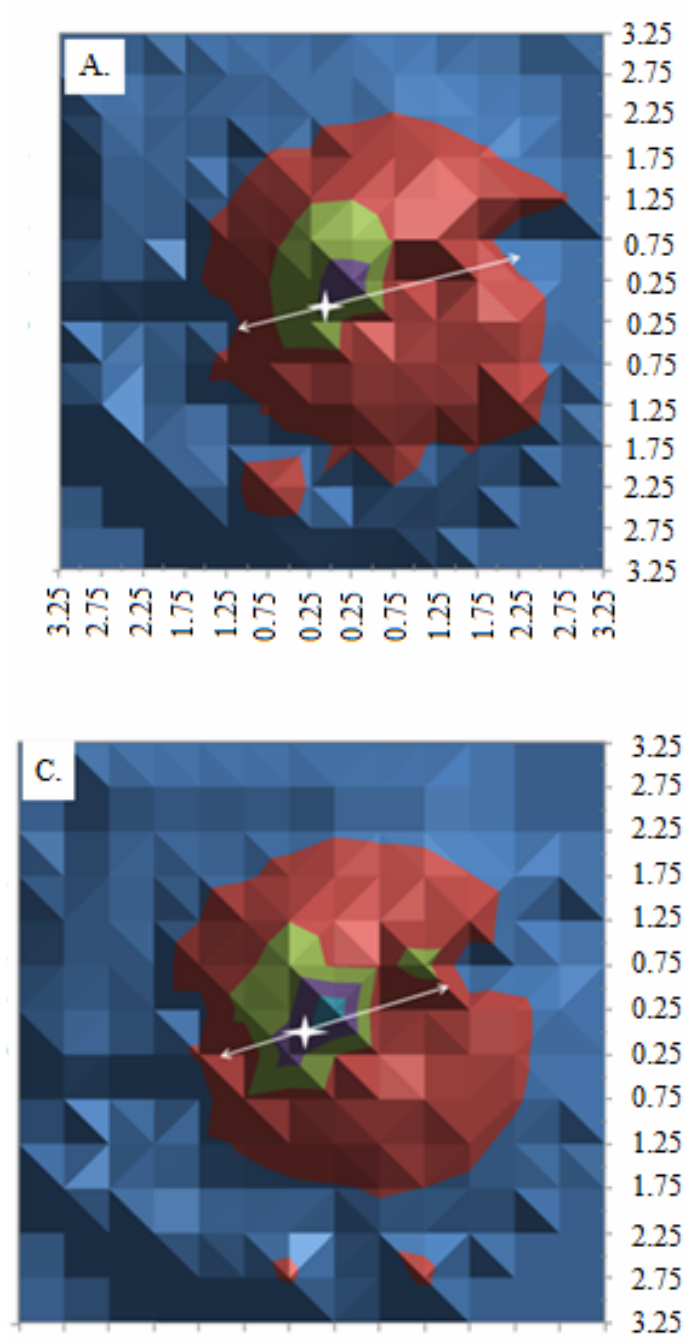

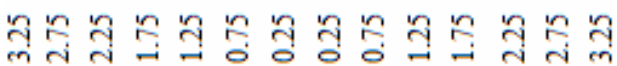

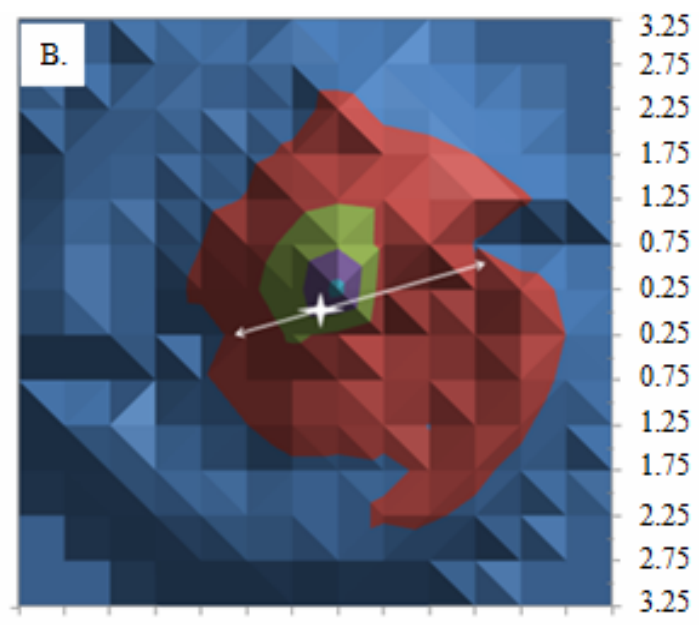

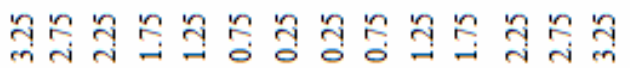

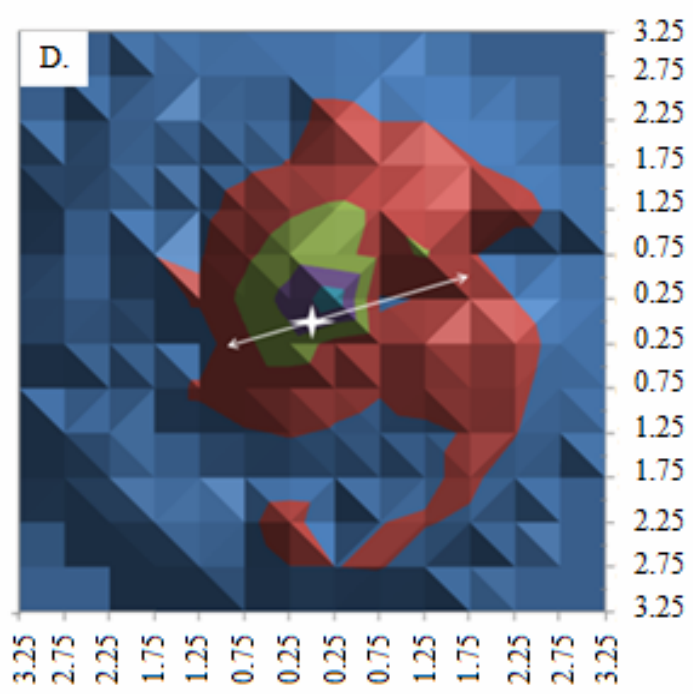

Collector distance from micro-sprinkler $(\mathrm{m})$

+ Position of micro-sprinkler $\leftrightarrow$ Direction of modular bridge

$\because 4-5 \quad \square-4=2-3=1-2 \quad \square 0-1$

Application intensity $\left(\mathrm{mm} \mathrm{h}^{-1}\right)$ 
Figure 8. Wetting isograms of used micro-sprinkler (A) 2, (B) 4, (C) 6, and (D) 9.
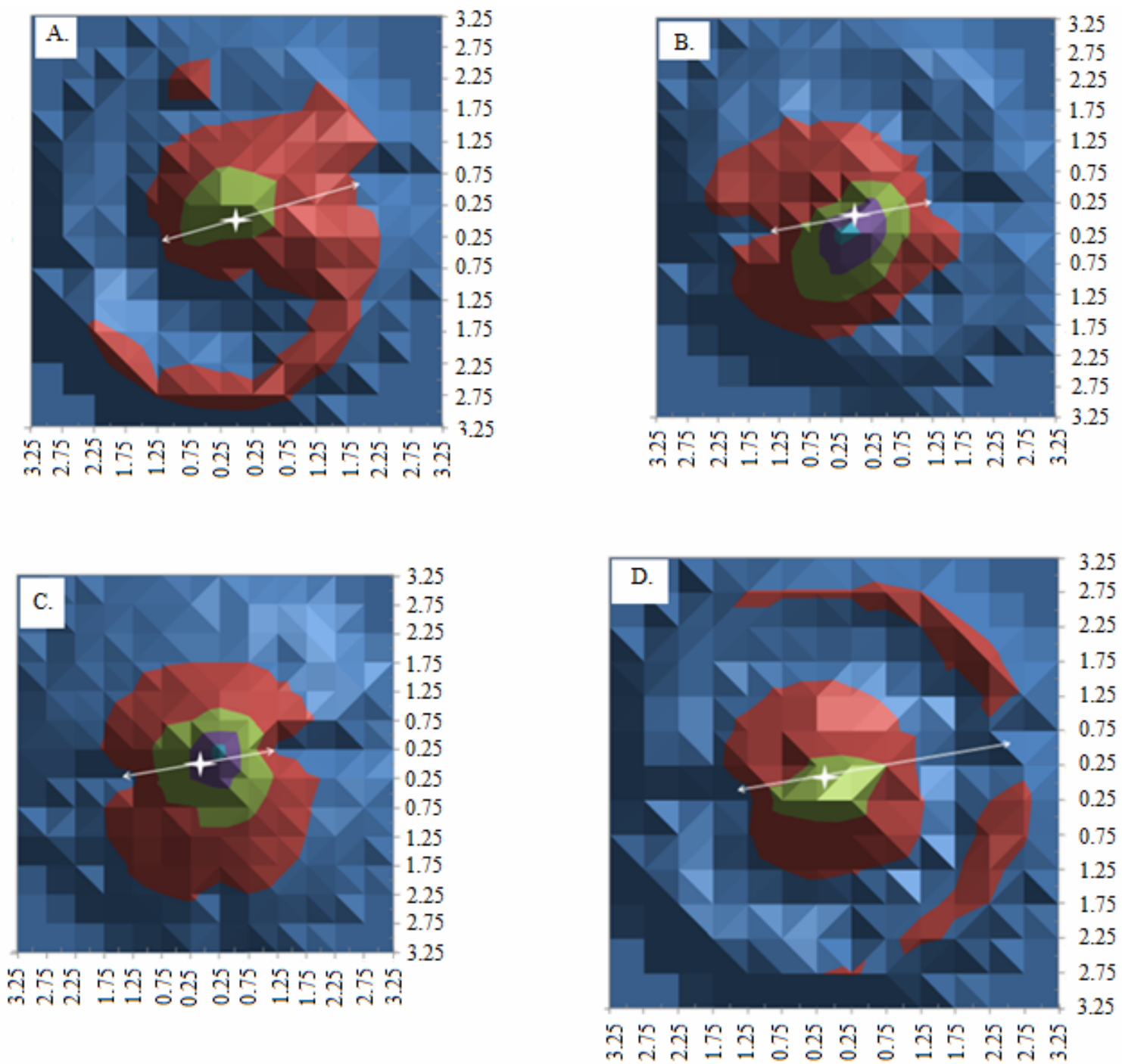

Collector distance from micro-sprinkler $(\mathrm{m})$

+ Position of micro-sprinkler $\leftrightarrow$ Direction of modular bridge

$\because 4-5 \quad=3-4=2-3 \quad \square=1-2 \quad \square 0-1$

Application intensity $\left(\mathrm{mm} \mathrm{h}^{-1}\right)$

\section{Conclusions}

The studied new and used micro-sprinklers (with 9 years of use) did not differ in terms of the coefficient of manufacturing variation and flow, and were rated as excellent.

The coverage diameters of the new and used micro-sprinklers were $6 \mathrm{~m}$, which are similar to the values given in the manufacturer's catalog.
There were no significant differences between the flow rates of the new and used micro-sprinklers when subjected to the same pressure; however, there were differences in flow rates within the pressure compensation range, and therefore these could not be considered as perfectly self-compensating.

The new and used micro-sprinklers did not differ in mean flow rate variations, which were greater 
than $2.5 \%$ (unacceptable). They also did not differ in maximum variations, which were greater than $10 \%$ (unacceptable) only at $250 \mathrm{kPa}$.

The CUC values and distribution uniformity were not statistically different for the new and used micro-sprinklers.

When installed in an irrigation system, the useful life of the emitters may be considered greater than 9 years or $4265 \mathrm{~h}$ of operation for crop and system management.

\section{References}

ASSOCIAÇÃO BRASILEIRA DE NORMAS TÉCNICAS - ABNT. Irrigação localizada: microaspersores requisitos gerais e métodos de ensaio. Projeto 04:015.08-015. Rio de Janeiro: ABNT, 2004. 15 p.

AMERICAN SOCIETY OF AGRICULTURAL AND BIOLOGICAL ENGINEERS - ASABE. Design and installation of microirrigation systems. ASABE STANDARDS 2008, EP405.1 APR1988 (R2008). St. Joseph: ASABE, 2008. 6 p.

CONCEIÇÃO, M. A. F.; COELHO, R. D. Efeito do vento sobre a distribuição de água por Microaspersores DAN 2001. Irriga, Botucatu, v. 9, n. 1, p. 62-71, 2004.

CUNHA, F. F.; PORDEUS, R. V.; MARACAJÁ, P. B.; FREITAS, R. S.; MESQUITA, L. X. Manejo de microirrigação baseado em avaliação do sistema na cultura do meloeiro. Revista Caatinga, Mossoró, v. 21, n. 3, p. 147$155,2008$.
CUNHA, M. D.; CUNHA, M. L.; FREIRE, O. J. Avaliação de desempenho do microaspersor Amanco $63 \mathrm{~L} \mathrm{~h}^{-1}$ em condições de campo. Holos, Natal, v. 5, p. 23-27, 2010.

FRIZZONE, J. A.; FREITAS, P. S. L.; REZENDE, R.; FARIA, M. A. Microirrigação: gotejamento e microaspersão. Maringá: Eduem, 2012. 356 p.

LEMOS FILHO, M. A. F.; ZANINI, J. R.; SILVA, E. R.; CAZETTA, J. O.; FERRAUDO, A. S. Sistema com aeração, decantação e filtragem para a melhoria da qualidade de água em irrigação localizada. Engenharia Agrícola, Jaboticabal, v. 31, n. 3, p. 506-519, 2011.

MANTOVANI, E. C.; BERNARDO, S.; PALARETTI, L. F. Irrigação: princípios e métodos. 3. ed. Viçosa, MG: UFV, 2012. $355 \mathrm{p}$.

MIOLA, E. C. C.; VIELMO, A. L.; SANTOS, K. L.; SCHONS, R. L.; ROBAINA, A. D.; PEITER, M. X. Curva característica do microaspersor NaandanHadar 7110. Irriga, Botucatu, v. 14, n. 1, p. 95-101, 2009.

SANDRI, D.; MESQUITA, M.; BESSA, S. E.; PRADO, L. C. R. A. Influência do tempo de uso sobre as características hidráulicas do microaspersor do grupo modular. Engenharia Agrícola, Jaboticabal, v. 30, n. 6, p. 1089-1100, 2010.

SILVA, C. A.; SILVA, C. J. Avaliação de uniformidade em sistemas de irrigação localizada. Revista Científica Eletrônica de Agronomia, Garça, v. 4, n. 8, p. 1-17, 2005. Disponível em: <http://www.revista.inf.br/agro/artigos/ artigo08.pdf $>$. Acesso em: 21 jan. 2013.

SOUZA, J. A. R.; DENICULI, W.; BATISTA, R. O.; VAL, J. C. C.; MATOS, A. T. Caracterização hidráulica de microaspersor aplicando água limpa, água residuária de avicultura e de bovinocultura. Engenharia na Agricultura, Viçosa, MG, v. 13, n. 3, p. 161-172, 2005. 